\title{
Duwweltjies en verantwoordelikheid
}

Min Afrikaanssprekendes sal seker ontken dat Afrikaans, spesifiek Standaardafrikaans, deesdae onder groot druk is. In sy hoër funksies -byvoorbeeld in ons howe (Engels moet die taal van rekord wees), tersiêre instellings, die handel en nywerheid, die owerheidswese - word Afrikaans toenemend'n bedreigde spesie. Dit wil vir hierdie skribent voorkom asof party mense - dikwels aanbieders van klets- of tydskrifprogramme en diegene met wie hulle praat, om nie van sportafrigters en spelers te praat nie - dit as benede hulle beskou om goeie Afrikaans te praat, asof dit "onkoel" is, gewis nie polities korrek nie. Dit lyk soms asof daar 'n soort kollektiewe skuldgevoel oor Afrikaans is weens apartheid in die algemeen en dalk gebeure soos Soweto 1976.

Beteken die veranderde politieke bedeling en die druk op Afrikaans dat 'n mens jou nie teen onsinnige politieke korrektheid en verloedering mag uitspreek nie?(Ek weet verloedering is eintlik 'n Nederlandse woord, maar een van die $W N T$ se betekenisonderskeidings is presies wat ek bedoel: "Door onzorgvuldige behandeling, verwaarloozing, slordigheid in een minderen staat gebracht worden".) Moet ons maar net gedwee toesien en dankie sê dat iets darem nog in Afrikaans is, in welke vorm ook al?

Verlede jaar het die DStv-kanaal kykNET sy 20ste bestaansjaar gevier, 'n merkwaardige prestasie; Afrikaanssprekendes kan met reg dankbaar daaroor en trots daarop wees. Tydens die vieringe het talle mense ook getuig van hoeveel kykNET bygedra het tot die kunste, die vermaaklikheidsbedryf en so meer; dit is ongetwyfeld so.

Hoeveel sal dit egter op die ou end tot die koste van enige produksie of program bydra as die vervaardigers'n kundige persoon kry om seker te maak dat hulle titels, veral die slottitels, aan Afrikaans se spelreëls voldoen? Sal kykNET minder programme kry of sal dit hom meer kos as hy vereis dat alle skriftelike Afrikaans in sy programme minstens aan Standaardafrikaans se spelreëls voldoen?

Die slottitels van party programme/reekse is beter as ander s'n, maar sonder uitsondering is daar foute in, veral wat vas of los skryf betref. Dit lyk amper asof die hantering van samestellings volkome lukraak is, want wat los, vas of met'n koppelteken vas geskryf word, is heeltemal onsistematies. Dikwels staan van ondergenoemde voorbeelde direk by mekaar.

Die volgende voorbeelde kom uit die slottitels van drie onlangse kykNET-reekse wat na my mening baie goeie reekse was.Dié reekse, soos wat deesdae skynbaar deurgaans gedoen word, is van Engelse subtitels voorsien, maar daarin, ironies genoeg, het ek nog selde of nooit sulke blatante flaters gesien nie.

'n Mens darem kan verwag dat basiese spelreëls van Afrikaans gevolg word. Naas 'n noodsaaklike hulpbron soos die $A W S$, is daar ook Leon van Nierop se lys met sulke termegetiteld Wat is in 'n naam?: Die betekenis van slottitels in rolprente. Daar is dus geen verskoning vir sulke slordige taalgebruik nie.

Adverteerders en hulle reklamemaatskappye is ewe skuldig. 'n Groot Afrikaanse jeugbeweging het onlangs 'n groot kleuradvertensie op 'n koerantvoorblad gehad wat lui: "Kinders wie kamp, is gelukkiger ...”.'n Bekende mynmaatskappy het'n radioadvertensie gehad waarin die stemkunstenaar verkondig: "Ons gaan net plekke toe as jy plekke gaan!". Tans het'n groot (voorheen hoofsaaklik Afrikaanse) versekeringsmaatskappy 'n radioadvertensie waarin gesê word hy sal kan help "as die weer lelik draai". Behoed ons! 


\begin{tabular}{|c|c|c|}
\hline In slottitels & In plaas van: & Kommentaar \\
\hline Teksgedrewe-Produksies & Teksgedrewe Produksies & $\begin{array}{l}\text { Daar is tog geen koppelteken nodig nie, } \\
\text { want dis 'n gewone b.nw. voor'n s.nw. }\end{array}$ \\
\hline Lyn-vervaardiger & Lynvervaardiger & $\begin{array}{l}\text { Daar is geen rede om met 'n koppelteken } \\
\text { vas te skryf nie. Dis 'n gewone, eenvou- } \\
\text { dige samestelling. }\end{array}$ \\
\hline Mede-vervaardiger & Medevervaardiger & $\begin{array}{l}\text { Soos bo; sonder koppelteken vas. } \\
\text { Sien } A W S, \text { r. } 12.34 \text {. }\end{array}$ \\
\hline Assistentregisseur $\checkmark$ & & $\begin{array}{l}\text { Heeltemal korrek, maar hoekom dan } \\
\text { "mede-vervaardiger" soos hier bo? }\end{array}$ \\
\hline $\begin{array}{l}\text { Produksie Bestuurder } \\
\text { Produksie Assistent } \\
\text { Produksie Rekenmeester }\end{array}$ & $\begin{array}{l}\text { Produksiebestuurder } \\
\text { Produksieassistent (of } \\
\text { Produksie-assistent) } \\
\text { Produksierekenmeester }\end{array}$ & Gewone, eenvoudige samestellings. \\
\hline Digitale Beeld Tegnikus & $\begin{array}{l}\text { Digitalebeeldtegnikus of } \\
\text { Tegnikus: Digitale Beeld }\end{array}$ & $\begin{array}{l}\text { In eersgenoemde skryfwyse moet die } \\
\text { b.nw. digitale vas geskryf word omdat } \\
\text { dit beeld bepaal, nie tegnikus nie. } \\
\text { Vgl. groenvyekonfyt (AWS, r. 15.27). } \\
\text { Omdat mense dikwels skrik vir sulke } \\
\text { samestellings, is omstelling soms 'n alter- } \\
\text { natief. }\end{array}$ \\
\hline $\begin{array}{l}\text { Kuns Assistent } \\
\text { Kunsregisseur } \checkmark\end{array}$ & Kunsassistent & $\begin{array}{l}\text { Dit is gewoon onbegryplik dat die } \\
\text { een verkeerdelik los en die ander korrek } \\
\text { vas geskryf word. }\end{array}$ \\
\hline $\begin{array}{l}\text { Eenheidsbestuurder } \checkmark \\
\text { Eenheids Assistent }\end{array}$ & & $\begin{array}{l}\text { Soos bo; te meer onbegryplik omdat daar } \\
\text { 'n verbindings-s is. }\end{array}$ \\
\hline Na-Produksie Toesighouer & $\begin{array}{l}\text { Naproduksietoesighouer of } \\
\text { Toesighouer: Naproduksie }\end{array}$ & \\
\hline Hotel gaste & Hotelgaste & $\begin{array}{l}\text { 'n Doodeenvoudige tweeledige same- } \\
\text { stelling. }\end{array}$ \\
\hline $\begin{array}{l}\text { Klank Na-Produksie } \\
\text { Fasiliteite }\end{array}$ & $\begin{array}{l}\text { Klanknaproduksiefasiliteite } \\
\text { of Naproduksiefasiliteite: } \\
\text { Klank }\end{array}$ & $\begin{array}{l}\text { Hier was klaarblyklik geen benul van } \\
\text { samestelling in Afrikaans nie. Indien } \\
\text { die samestelling as te lank of te moeilik } \\
\text { leesbaar beskou word, gebruik omstelling. }\end{array}$ \\
\hline Hoof tema musiek & Hooftemamusiek & \\
\hline Agter die skerms fotografie & $\begin{array}{l}\text { Agter-die-skerms-fotografie } \\
\text { of Fotografie agter die }\end{array}$ & $\begin{array}{l}\text { Vir die koppeltekenmoontlikhede, } \\
\text { skerms sien } A W S, \text { r. } 12.21 .\end{array}$ \\
\hline $\begin{array}{l}\text { Produksiekoördineerder } \checkmark \\
\text { Produksie assistent } \\
\text { Produksie drywer }\end{array}$ & $\begin{array}{l}\text { Produksieassistent of } \\
\text { Produksie-assistent } \\
\text { Produksiedrywer }\end{array}$ & $\begin{array}{l}\text { Dit is eenvoudig onverstaanbaar waarom } \\
\text { die een kombinasie korrek en die ander } \\
\text { twee verkeerd geskryf word. }\end{array}$ \\
\hline Klank effekte redigeerder & $\begin{array}{l}\text { Klankeffekteredigeerder } \\
\text { of Redigeerder: } \\
\text { Klankeffekte }\end{array}$ & \\
\hline
\end{tabular}

[Afkortings: AWS - Afrikaanse woordelys en spelreëls (2017); r. - reël; b.nw. - byvoeglike naamwoord; s.nw. - selfstandige naamwoord. Hoofletters is soos in die betrokke slottitels.] 
Daar is nog talle eenvoudige tweeledige samestellings wat verkeerdelik los geskryf is, soos *drama kinders, *fokus tegnikus, *assistent regisseur, *kamera assistent, *kleur menger, *dialoog redigeerder.

As 'n mens nie Engels ken nie, sal jy nie sulke Afrikaans verstaan nie. Is daar dan niemand by die adverteerders wat die reklamekopie taalkundig kan nagaan nie? Kan die stemkunstenaars nie sê dis on-Afrikaanse goed wat julle hier opdis nie?

My betoog is dat almal vir wie Afrikaans van belang is, by die betrokkenes en in die openbaar beswaar maak teen dié soort verloedering van Standaardafrikaans. Dit is en bly ons verantwoordelikheid.

JD (Tom) McLachlan

E-pos: tommcl@whalemail.co.za 